\title{
PENGALAMAN KEPALA RUANGAN MENGIDENTIFIKASI PENYAKIT DAN KECELAKAAN AKIBAT KERJA: STUDI QUALITATIF
}

\section{[EXPERIENCE OF HEAD NURSE IN IDENTIFYING OCCUPATIONAL DISEASE AND ACCIDENTS: A QUALITATIVE STUDY]}

\author{
Rahma Yulis \\ Program Studi Ilmu Keperawatan, Sekolah Tinggi Ilmu Kesehatan Makassar \\ e-mail : rahmayulis30@gmail.com \\ DOI : 10.47718/jpd.v8i01.1140
}

ABSTRAK

ABSTRACT
Latar Belakang: Tingginya risiko penyakit dan kecelakaan akibat kerja pada perawat di rumah sakit diakibatkan oleh kegagalan manajer dalam menciptakan lingkungan kerja yang aman. Tujuan: untuk mendapatkan gambaran pengalaman kepala ruangan ketika mengidentifiikasi penyakit dan kecelakaan akibat kerja yang terjadi di ruangan mereka. Metode: yang peneliti gunakan adalah metode kualitatif dengan pendekatan studi fenomenologi. Partisipan pada penelitian ini berjumlah 7 kepala ruangan dengan pengalaman kerja lebih dari dua tahun. Data dari studi ini dikumpulkan melalui wawancara mendalam, kemudian dianalisis dengan menggunakan metode Collaizi. Hasil: Hasil penelitian teridentifikasi 5 tema yaitu: 1) mencari informasi tentang penyakit dan kecelakaan akibat kerja yang menimpa perawat, 2) berbagai penyakit dan kecelakaan akibat kerja yang sering terjadi, 3) menganalisis penyebab penyakit dan kecelakaan yang terjadi, 4) mengevaluasi akibat yang ditimbulkan apabila perawat sakit atau cedera, 5) melaporkan kejadian ke pihak terkait. Kesimpulan: penelitian ini mengungkapkan bahwa kepala ruangan menyadari pekerjaan sebagai perawat berisiko tinggi mengalami cedera, stres, tertular dan menularkan penyakit ke orang sekitarnya. Studi ini juga menemukan bahwa perbaikan fasilitas, menciptakan lingkungan yang aman, peningkatan kesadaran perawat untuk menjaga keselamatan diri, bisa menjadi upaya mencegah penyakit atau kecelakaan akibat kerja.

Kata Kunci: penyakit dan kecelakaan akibat kerja, kepala ruangan.

Introduction: A high risk of Occupational Disease and Accidents for nurses in hospitals is caused by failure of managers in creating a safe work environment. Aim: the purpose of this study was to describe the experience of the head nurse 
when identifying Occupational Disease and Accidents that occur in their ward. Method: this research used a qualitative design with a phenomenological approach. Participants in this study were 7 head nurses with working experience more than two years. The data from this study were collected through in-depth interviews, then analyzed using Collaizi Method. Results: 5 Themes was identified in this study: 1) seeking information about Occupational Disease and Accidents that affecting nurses, 2) various Occupational Disease and Accidents that often occur, 3) analyzing the causes of Occupational Disease and Accidents, 4) evaluating the consequences if nurses are sick or injured, 5) reported the incident to related party. Conclution: this study revealed that the head nurses were aware of their job as nurse in which at high risk of experiencing injury, stress, transmitted and transmitting the disease to those around them. The study also found that improving facilities, creating safe environment, raising nurses' awareness to maintain personal safety could be some efforts to prevent Occupational Disease and Accidents.

Key words: occupational disease and accidents, head nurse.

PENDAHULU AN
Perawat sebagai tenaga kesehatan yang mendampingi pasien selama 24 jam rawan mengalami kondisi yang mengancam keselamatan. Bahaya potensial yang dihadapi perawat adalah bahaya psikologis, biologis, fisik, kimia dan ergonomis, (Lindsey, Hutchinson, \& Mellor, 2015: Zavala, Suazo, \& Klijn, 2014).

Berbagai bahaya potensial yang dihadapi perawat mengindikasi bahwa rumah sakit adalah tempat kerja berisiko tinggi bagi keselamatan dan kesehatan perawat International Labour Organization (ILO) (2016) menyatakan bahwa risiko petugas kesehatan terkena cedera dan penyakit akibat kerja lebih besar dibanding tempat kerja yang lain. Hal ini disebabkan karena rumah sakit merupakan tempat kerja yang kompleks. Di rumah sakit kita bisa menemukan berbagai jenis tenaga kesehatan, pasien, penyakit, obat-obatan, keahlian serta peralatan yang canggih (Kondarus, 2012). Rumah sakit juga menyediakan beragam layanan kesehatan, seperti: rawat inap, gawat darurat, kamar bedah, perawatan intensif, fasilitas 
diagnostik, layanan farmasi dan layanan spesialis (Kozier, Erb, Berman \& Snyder, 2004/2010). Kompleksitas inilah yang menyebabkan terjadinya penyakit dan kecelakaan akibat kerja pada perawat, misalnya: tertular penyakit pasien, gangguan muskuloskletal akibat kesalahan posisi dalam membantu pasien pindah tempat tidur dan merubah posisi pasien, serta rawan mengalami tindak kekerasan verbal dan fisik dari pasien maupun pengunjung (Efstathiou, Papastavrou, Raftopoulos \& Merkouris, 2013; Fasanya dan Dada, 2015; Rogers, Buckheit \& Ostendorf, 2013).

Studi pendahuluan di tempat peneltian, data Tim Keselamatan dan Kesehatan Kerja (K3) rumah sakit tahun 2015 terjadi kejadian kecelakaan kerja: tertusuk jarum sebanyak 21 perawat, cedera karena benda tajam sebanyak 2 perawat, tekena cairan tubuh pasien infeksius sebanyak 1 perawat, terpeleset sebanyak 1 perawat, serta terkena tumpahan merkuri dari air raksa tensimeter sebanyak 1 perawat. Angka ini adalah angka kecelakaan kerja yang dilaporkan ke Tim K3 rumah sakit. Namun menurut ketua Tim K3 masih banyak kecelakaan kerja yang tidak terlapor.

Kejadian penyakit dan kecelakaan akibat kerja yang masih dialami perawat dianggap sebagai suatu kegagalan manajemen dalam menyelanggarakan lingkungan kerja yang aman bagi perawat. Marquis \& Huston (2003/2010) menyatakan bahwa salah satu fungsi manajer adalah memastikan lingkungan kerja yang aman bagi pekerja. Kebutuhan informasi tentang berbagai pengalaman kepala ruangan menghadapi perawat yang cedera maupun sakit, menjadi sangat penting. Menurut Bird dalam Teori Gunung Esnya (Iceberg) bahwa kejadian hari ini yang hanya menyebabkan lecet, dikemudian hari bisa jadi menyebabkan cedera yang fatal seperti amputasi (Hadipoetro, 2014). Oleh karena itu penyebab 
kecelakaan apapun harus selalu mendapat perhatian yang sama.

Pada studi ini peneliti bermaksud mengeksplorasi lebih mendalam pengalaman kepala ruangan melalui studi fenomenologi untuk menjawab pertanyaaan penelitian 1) Apa ungkapan arti dari pengalaman kepala ruangan dalam mengidentifikasi penyakit dan kecelakaan kerja yang dialami perawat di ruangan mereka. Dengan pengalaman ini memungkinkan manajer keperawatan untuk melakukan pencegahan penyakit dan akibat kerja dimasa yang akan datang.

METODE

PENELITIAN
Metode penelitian yang peneliti gunakan pada penelitian ini adalah metode kualitatif dengan pendekatan fenomenologi. Fenomenologi adalah suatu metode yang digunakan untuk menggali pengalaman hidup seseorang (Afiyanti \& Rachmawati 2014; Dharma 2011), sebab pengalaman yang dirasakan setiap individu terhadap satu fenomena bisa saja berbeda (Polit \&, Beck, 2012). Tujuan dari penelitian ini adalah mengkaji pengalaman kepala ruangan dalam mengidentifikasi penyakit dan kecelakaan akibat kerja yang terjadi di ruangan mereka. Hasil ini diharapkan bisa memperkaya pemahaman pembaca mengenai suatu pengalaman hidup tertentu.

Penelitian ini menggunakan kepala ruangan yang bekerja di sebuah rumah sakit umum tipe A di Jakarta Timur. Partisipan dipilih dengan menggunakan metode purposive sampling dengan tipe sampling variasi maksimum. Artinya partisipan dipilih sesuai dengan tujuan penelitian dan kriteria inklusi (Polit \& Beck, 2012). Memenuhi persyaratan studi ini, kriteria partisipan adalah: 1) perawat yang telah menjabat sebagai kepala ruangan lebih dari dua tahun, 2) bersedia menjadi partisipan dengan memberikan persetujuan melalui informed consent. Pemilihan partisipan dan proses menjalin komunikasi ke partisipan 
dibantu oleh Kepala Bidang Pelayanan Keperawatan.

Fokus penelitian fenomenolgi adalah kedalaman dan proses. Peneliti melibatkan 7 partisipan sebab peneliti telah mencapai saturasi data pada partisipan ketujuh. Berdasarkan pertimbangan variasi data dan kelengkapan informasi, partisipan dipilih dari lokasi berbeda yaitu: ruang operasi, IGD, rawat inap pasien TB dan TB MDR, rawat inap pasien bedah, VVIP dan ruang kemoterapi. Pemilihan kelima ruangan ini didasarkan pada penelitian Shu-Ti, JenHuai, Huang, Chih-Hsun, dan Li-Yin (2013) bahwa ruang operasi, IGD, kamar bersalin, ruang inap dan intensif berisiko tinggi menyebabkan kecelakaan kerja atau depresi pada perawat dibanding rawat jalan dan administrasi.

Data dari studi ini dikumpulkan melalui wawancara mendalam, perekaman, membuat transkrip verbatim dan catatan lapangan. Sebelum melakukan wawancara peneliti, memberikan kesempatan ke partisipan untuk mengisi data demografi, untuk memberi gambaran singkat tentang partisipan.

Analisa data menggunakan metode Collaizi (Polit \& Beck, 2012). Keseluruhan proses penelitian mengacu pada prinsip etika penelitian Polit dan Beck (2012) yaitu autonomy, beneficience, dan justice. Keabsahan dan validitas data menggunakan empat langkah yaitu: credibility, confirmability, dependability dan transferability.

HASIL DAN

PEMBAHASA

$\mathbf{N}$
Partisipan pada penelitian ini adalah 7 kepala ruangan yang telah bekerja sebagai kepala ruangan lebih dari dua tahun. Karakteristik partisipan yaitu: terdiri dari 7 perempuan dan 1 laki-laki, dengan usia yang bervariasi dari 36 sampai 41 tahun. Masa kerja sebagai perawat dari 10 sampai 21 tahun, dan sebagai kepala ruangan 2 tahun 2 bulan sampai 6 tahun. Latar belakang pendidikan partisipan semuanya sama yaitu Ners. Status pernikahan semuanya telah menikah, 
sedangkan untuk suku bervariasi yaitu: Sunda, Jawa, Padang dan Batak.

Analisis tematik pada penelitian ini menghasilkan 5 tema yaitu; 1) Mencari informasi tentang kecelakaan atau penyakit akibat kerja yang menimpa perawat, 2) Berbagai penyakit dan kecelakaan akibat kerja yang sering terjadi, 3) Menganalisis penyebab kecelakan atau penyakit akibat kerja, 4) Mengevaluasi akibat yang ditimbulkan apabila perawat cedera/ sakit, 5) Melaporkan kejadian ke pihak terkait.

\section{Tema 1. Mencari informasi tentang kecelakaan/ penyakit akibat kerja yang menimpa perawat.}

Pengalaman tentang apa yang dilakukan kepala ruangan ketika mendengar laporan jika ada perawatnya yang tiba-tiba kecelakaan kerja? Pertanyaan tersebut menjadi awal wawancara saya kepada partisipan. Hasil wawancara menunjukkan bahwa lima partisipan segera merespon ketika mendapatkan laporan dengan mencari informasi tentang kecelakaan/ penyakit akibat kerja yang menimpa perawat. Respon pertama yang dilakukan partisipan adalah mendengarkan laporan perawat terlebih dahulu. "Jadi kita dengarkan dulu, cari permasalahnya apa" (P2).

Respon cepat ketika mendengar laporan kecelakaan kerja diangap sebagai bagian dari tupoksi pekerjaan dan juga sebagai bentuk kepatuhan terhadap alur yang telah di tetapkan rumah sakit. "Jadi pentingnya kayak gitu. Kalau kita ngga respon apa namanya kita bisa kena masalah" (P7).

Langkah selanjutnya adalah mendatangi lokasi kejadian untuk mencari informasi kejadian. "Jadi...lihat di TKP kayak gimana, baru kita selesaikan masalah itu" (P2). 
Tema 2.

Berbagai jenis kecelakaan dan penyakit akibat kerja yang sering terjadi.

Gambaran berbagai jenis kecelakaan dan penyakit akibat kerja yang sering dialami oleh kepala ruangan, peneliti peroleh dari enam partisipan dari total tujuh partisipan. Keempat partisipan menceritakan pengalaman mereka tentang berbagai jenis kecelakaan akibat kerja yang sering terjadi di ruangan berdasarkan laporan perawat dan mereka pengalaman mereka sendiri yaitu: tertusuk jarum dan terjatuh.

"Paling sering itu tertusuk jarum...lebih kurang sekitar tiga kejadian". (P5).

Terjatuh disini diceritakan responden terjadi dalam berbagai kondisi. Misalnya: terjatuh karena terpeleset di lantai licin, terjatuh di ram/ selasar karena karet landasan sebagai alat bantu pengereman beberapa yang pinggirannya terkelupas, tergelincir di ram ketika membawa brankar pasien, serta terjatuh dalam posisi duduk.

"Kadang ada g terpeleset, tergelincir, menggelinding ke bawah. ada juga yang pernah jatuh terduduk tapi ga parah" (P5).

Kecelakaan jatuh disini tidak hanya dialami oleh perawat namun salah satu partisipan juga pernah mengalami bahkan sampai tiga kali. Frekuensi jatuh bisa dibilang cukup sering, akan tetapi berdasarkan pengalaman satu partisipan tingkat keparahan akibat jatuh selama ini belum ada yang tergolong cukup parah sehingga harus mendapatkan tindakan operasi.

"Pernah dulu ada yang jatuh, sayapun pernah 3 kali jatuh. Tapi belum ada yang misalnya jatuh dan harus di operasi". (P1

Kecelakaan lain yang pernah dialami perawat adalah terkilir, tertimpa plafon 
dan tertimpa rel gorden.

"Disinipun anak buah ketimpa plafon, ketimpa rel gorden" (P7).

Penyakit akibat kerja yang pernah dialami perawat di ruangan adalah: sakit kepala, Hepatitis B, batuk flu, masuk angin, BTA positif, resisten obat karena sering terpapar dengan obat-obatan, peningkatan SGOT SGPT, Hernia Nukleus Pulposus (HNP).

Menurut salah satu partisipan penyakit yang dialami perawat memang belum bisa dipastikan apakah berasal dari rumah sakit atau dari luar, tapi besar kemungkinan berasal dari rumah sakit.

"Satu yang positif Hepatitis B. Kita tidak tahu pasti dia dapat dari mana, tapi kita sudah cek anak dan suaminya semua negatif... jadi menurut loe kemungkinan dia kena dimana" (P7).

Penyakit lain yang dihadapi perawat adalah stres dan beban psikologis. Beban psikologis dikeluhkan oleh tiga partisipan. Beban psikologis yang dialami perawat berasal dari keluarga pasien, atasan, kepala ruangan, supervisor dan assesor. Beban psikogis ini bisa berupa kritikan atau teguran atas pekerjaan mereka.

Kecelakaan lain yang berat seperti kecelakaan mental...Banyak yang orang keluhkan adalah kecelakaan mental.....Dari keluarga pasien dari atasan: saya, supervisor atau assessor... Misalnya mereka menegur bahwa ini tidak tepat,. Padahal mereka sudah berupaya optimal" (P2).

Selain kekerasan verbal, beban psikologis juga berasal dari beban kerja yang tinggi dan harus meghadapi berbagai karakter pasien dan keluarga pasien.

"Pressure cukup tinggi: keluarga pasien, menghadapi semua lapisan masyarakat dan berpacu dengan waktu. Tekanan darimana-mana, namaya orang 
panik, semuanya minta diprioritaskan. Orang yang datang ke IGD mereka harus membentak petugas duluan. Pasiennya overload, sementara pasien ga bisa ditahan masuk IGD... ruang rawat penuh pasien ga bisa keluar....Semua sorotan ke IGD itu banyak yah. Jadi semua kekurangan adanya dari IGD" (P4).

\section{Tema 3. Menganalisis penyebab kecelakan/ penyakit akibat kerja.}

Tujuh partisipan mengungkapkan ada enam penyebab terjadinya kecelakaan atau penyakit akibat kerja di ruangan mereka. Pertama, menurut dua partisipan fasilitas yang tersedia di rumah sakit belum sepenuhnya aman bagi pekerja.

"Dulu mengoplos obatpun tidak dilakukan di farmasi...tapi dikamar pasien karena saat itu belum ada ruang tindakan... dan yang mengerjakan adalah kita" (P7).

Kedua, menurut empat partisipan lingkungan yang belum aman bagi pekerja, seperti lantai yang terlalu licin, berlubang atau ada air yang tergenang. Selain lantai yang kurang aman, ram merupakan penyebab tersering perawat terpeleset sebab ram dinilai terlalu tinggi, licin dan karet landasannya licin jika kena hujan dan sudah mulai terkelupas di bagian pinggirnya.

Selasarnya...ditengah-tengahnya dikasi karet di sambung-sambung. Sering terkelupas dipinggirnya, terlipat...jadi terpleset dan jatuh" (P5).

Lingkungan yang belum aman lain menurut satu partisipan adalah siklus udara di ruang ber AC. "Kamar itukan ber AC jadi siklus udara tidak keluar, pasien yang dibuka jendelanya terus di matikan ACnya ngga mau" (P6).

Ketiga, menurut enam partisipan beban kerja yang tinggi baik fisik maupun mental serta tenaga yang kurang menyebabkan kelelahan dan kurang 
konsentrasi. Beban fisik yang dialami perawat misalnya: rasio pasien dan perawat dirasa tidak sebanding, jam kerja yang memanjang. Beban kerja disini berat. Kadang ada satu operasi dari jam 8 -14 masih jalan" (P1).

Beban mental yang dialami perawat misalnya pendokumentasian yang terlalu banyak, tekanan dari profesi lain. Semua beban kerja ini menyebabkan perawat kelelahan sehingga kurang konsentrasi dan akhirnya berefek kecelakaan kerja seperti tertusuk jarum.

Tertusuk jarum... Kelelahan jadi ngga lagi memperhatikan prosedur, mungkin beban kerjanya. Maksudnya repot jadi dia mungkin buru-buru." (P3)

Keempat, menurut dua partisipan perawat masih mengerjakan pekerjaan non keperawatan misalnya mengambil darah, bahkan terkadang perawat harus mengambil sendiri hasil pemeriksaan penunjang pasien mereka.

"Buru-burunya yah gimana, jumlah tempat tidur disanakan 40, terus dinas 3 orang per shift...Terutama ngambil darah itu paling banyak disana...trus yang ngambil darah bukan petugas lab.nya, tapi kita yang ngambil"(P5).

Kelima, menurut empat partisipan kesadaran perawat masih kurang tentang pentingnya menjaga keselamatan dan kesehatan diri. Misalnya ketaatan terhadap SOP atau kepatuhan memakai APD masih kurang, tidak melapor ke kepala ruangan jika sedang sakit, terkadang gizi tambahan yang diberikan kepada perawat sering dibawa pulang untuk keluarga, posisi yang tidak tepat saat melakukan tindakan, dan pengetahuan tentang obat-obat berbahaya masih kurang.

"Berbicara tentang keselamatan kerja...sekarang orang lebih peduli di banding dulu. Dulu orang memandang kemoterapi itu ngga berisiko" (P7).

Keenam, menurut satu orang perawat kurang pengalaman menjadi 
penyebab perawat mengalami kecelakaan kerja. "Tertusuk jarum... ada 3 kejadian. Rata-rata itu perawat baru... Karena dia baru, belum terbiasa dengan kerja yang harus cepat dan jumlah pasien sekian" (P5).

\section{Tema 4. Mengevaluasi akibat yang ditimbulkan apabila perawat cedera/ sakit}

Mengevaluasi akibat yang ditimbulkan dari kecelakaan atau penyakit akibat kerja yang dilakukan empat partisipan. Pertama, menurut dua partisipan pelayanan keperawatan dapat terganggu.

"Untuk melayani manusia yang melayani harus benar-benar sehat, kalau sakit melayaninya pasti ga maksimal" (P5).

Kedua, perawat yang tertular penyakit dari pasien, berisiko menularkannya ke orang-orang sekitarnya terutama keluarga. Ketiga, menyebabkan kerugian bagi rumah sakit, misalnya pembiayaan kesehatan perawat dan kerusakan fasilitas rumah sakit

"Di pasiennya rugi, rumah sakit alat rugi lebih banyak" (P3).

Keempat, menurut dua partisipan kecelakaan kerja bisa menyebabkan perawat yang cedera menjadi stres. "Stafnya biasanya stres, kalau habis ketusuk itu suka ada yang nangis" (P5).

\section{Tema 5. Melaporkan kejadian ke pihak terkait.}

Melaporkan ke bidang terkait di rumah sakit, misalnya ke PPI, Ka. Instalasi atau IPS atau manajem keperawatan yang dilakukan oleh tiga partisipan. "Lapor di PPI...PPI yang menentukan perlu untuk dilakukan pemeriksaan berkala... ke PPI yah diskusi atau konsultasi gimana...Lapor ke Ka. Instalasi kalau emang ada halhal yang memberatkan...supaya orang IPS atau rumah tangga memperbaiki... Kalau terkait IPS saya langsung lapor ke IPS yang menangani kalau fasilitas" (P5).

Berbagai penyakit dan kecelakaan kerja yang dialami perawat dan upaya 
kepala ruangan dalam mengidentifikasi penyebab dan akibat yang ditimbulkan menjadi tema-tema utama dalam penelitian ini. Tema- tema tersebut mengidentifikasi bahwa terdapat suatu tantangan yang besar bagi kepala ruangan dan manajer keperawatan dalam menciptakan lingkungan yang aman bagi perawat.

Penyakit dan kecelakaan akibat kerja yang dialami perawat, berdasarkan studi literatur yang ada saat ini mengindikasikna banyak kesamaan dari pengalaman-pengalam kepala ruangan, namun ada beberapa pula perbedaan. Seperti contoh penyakit akibat kerja yang dialami perawat pada studi ini adalah tertular penyakit dari pasien: TBC dan Hepatitis B, HNP, stres karena beban kerja yang tinggi, mengalami kekerasan verbal dan kekerasan fisik. Laporan-laporan ini menjadi sangat umum ditemukan pada studi-studi sebelumnya tentang penyakit dan kecelakaan akibat kerja pada perawat (Al-Ali, Al Faouri, \& Al-Niarat, 2015; Chen-Ying, Chia-Chen,, Jin-Lain, \& Keh-Ping, 2014; Mitrousi, Travlos, Koukia \& Zyga, 2014; Shimizu, Couto, Hamann, \& Branco, 2010).

Hasil dari studi menemukan bahwa IGD merupakan salah satu ruang yang paling sering mengalami kekerasan verbal, biasanya terjadi ketika pasien pertama kali masuk ke IGD. Dimana pada saat itu keluarga pasien panik dan ingin keluarga mereka diprioritaskan, sehingga terkadang mereka membentak petugas. Hasil penelitian yang sama oleh Ramacciati, Ceccagnoli \& Addey (2015) menemukan bahwa perilaku kekerasan baik fisik maupun verbal biasaya terjadi pada perawat di bagian IGD terutama ketika melakukan triage. Penelitian yang lain oleh Al-Ali et al. (2015) menemukan hal yang sama bahwa kekerasan verbal yang diterima dari pengunjung paling banyak terjadi pada situasi kritis $(42,3 \%)$ dan selama jam besuk $(36,1 \%)$. 
Penyakit akibat kerja yang berbeda dengan studi sebelumnya adalah sakit kepala, batuk, flu dan masuk angin akibat kehujanan ketika dalam perjalanan ke tempat kerja, resisten obat karena sering terpapar dengan obat-obatan, peningkatan nilai SGOT/SGPT. Beberapa penyakit ini adalah hal yang sering dialami perawat namun bisa saja tidak dilaporkan oleh perawaT.

Menurut kepala ruangan mendeteksi penyakit akibat kerja susah, karena tidak bisa dipastikan bahwa penyakit tersebut apakah berasal dari rumah sakit atau dari luar rumah sakit. Namun menurut satu partisipan, ketika suami dan anak partisipan yang terkena hepatitis B di cek, hasilnya negatif, jadi kemungkinan besar penyakitnya berasal dari rumah sakit. Mengatasi hal ini maka penting dilakukan pemeriksaan kesehatan pada perawat sebelum masuk kerja dan pemeriksaan rutin tiap tahun.

Hasil studi ini juga mengidentifikasi berbagai kecelakaan kerja yang dialami perawat yaitu: tertusuk jarum dan terjatuh. Hasil studi ini merupakan hal yang sangat umum ditemukan dari studi-studi sebelumnya. Penelitian oleh De Mendonca, De Oliveira, Neto, dan Da Silva (2015) didapatkan bahwa sekitar 48,8 \% perawat ICU pernah mengalami kejadian tertusuk jarum di area jari-jari tangan. Yeoh, Lockhart \& Wu (2013) menemukan bahwa penyebab lain cedera muskuloskeletal adalah jatuh di tempat kerja.

Terjatuh dalam studi ini diceritakan partisipan terjadi dalam berbagai kondisi. Misalnya terjatuh karena terpeleset di lantai yang licin, terjatuh kerena tersandung karet landasan ram yang sudah terkelupas, terjatuh dan tergelincir di ram ketika membawa brankar pasien. Efek jatuh menyebabkan beberapa perawat keseleo pada ekstremitas bawah atau sakit pada bagian bokong karena terjatuh dalam posisi duduk. Kecelakaan lain yang pernah dialami perawat yang mungkin 
berbeda dari studi lain adalah tertimpa plafon dan tertimpa rel gorden ketika sedang bekerja.

Berbagai penyakit dan kecelakaan kerja yang dialami perawat memicu kepala ruangan melakukan beberapa upaya pencegahan. Laporan dari 4 partisipan mereka mencari informasi tentang penyakit atau kecelakaan akibat kerja yang menimpa perawat dengan cara mendengarkan kesaksian dari orangorang yang terlibat dalam kejadian serta mendatangi langsung lokasi kejadian agar bisa menilai sendiri tingkat keparahannya.

Laporan lainnnya partisipan menganalisis penyebab. Hasil studi ini menemukan tujuh penyebab penyakit dan kecelakaan akibat kerja yaitu: 1) fasilitas yang tersedia di rumah sakit belum sepenuhnya aman bagi pekerja, misalnya pengoplosan obat kemoterapi di kamar pasien dan yang melakukan adalah perawat bukannya apoteker. 2) Lingkungan kerja yang tidak aman. Beberapa lantai masih terlalu licin, berlubang dan tergenang air, serta ram dinilai terlalu tinggi dan masih menggunakan karet sebagai landasan. Selain itu sirkulasi udara di ruangan ber AC belum aman, karena beberapa pasien terkadang tidak mau menuruti perintah untuk mematikan AC beberapa menit dan membuka jendela. 3) Beban fisik dan mental yang dirasa cukup berat sehingga mengakibatkan kelelahan. Misalnya rasio perawat dan pasien tidak sebanding, jam kerja yang terkadang memanjang khususnya di ruangan OK, pendokumentasian yang dinilai terlalu banyak, tekanan dari profesi lain. Pandangan yang sama oleh Mcintosh \& Sheppy (2013); Mitrousi et al. (2014) bahwa faktor penyebab stres ini adalah tingkat pendidikan, staf yang kurang, pekerjaan yang melelahkan, perawatan harian dengan pasien khusus, konflik interpersonal, konflik pada tuntutan pelayanan, misalnya tekanan untuk bekerja 
dengan cara yang lebih fleksibel atau hemat biaya sambil mempertahankan standar profesional, perubahan peran perawat, rasio perawat-pasien yang tidak seimbang dan serta faktor keterampilan.

Faktor penyebab selanjutnya adalah 4) perawat masih mengerjakan pekerjaan non keperawatan misalnya mengambil darah dan terkadang mengambil sendiri hasil pemeriksaan penunjang pasien. 5) kesadaran perawat masih kurang tentang pentingnya menjaga keselamatan dan kesehatan diri sehingga terkadang tidak bekerja sesuai SOP, pembagian gizi tambahan tidak dikomsumsi sendiri tapi dibawa pulang untuk keluarga, tidak menerapkan posisi yang ergonomis saat melakukan tindakan serta pengetahuan yang kurang tentang obat-obat berbahaya masih kurang. 6) pengalaman kerja yang kurang dan belum terbiasa dengan ritme kerja perawat di ruangan, menyebabkan kecelakaan tertusuk jarum sering dialami perawat baru.

Hasil dari analisis partisipan menunjukkan bahwa manajer belum optimal dalam mengatur tiga kompenen utama dalam Sistem Mananjemen Keselamatan dan Kesehatan Kerja (SMK3) rumah sakit yaitu kapasitas kerja, beban kerja, dan lingkungan kerja (Achmadi, 2014). Manajemen memegang peran penting untuk memantau bahaya di tempat kerja secara terus menerus sehingga dapat melindungi kesehatan kerja perawat (Hu, Luk, \& Smith, 2015).

Laporan lainnya partisipan menganalisis akibat dari sakit dan cedera yang dialami perawat. Hasil studi ini menemukan bahwa ada empat akibat yang ditimbulkan yaitu: perawat menjadi stres, perawat berisiko menularkannya penyakitnya ke orang-orang sekitarnya, pelayanan keperawatan dapat terganggu, menyebabkan kerugian bagi rumah sakit karena menanggung biaya perawatan dan perbaikan fasilitas. 
Laporan lainnya partisipan melaporkan kejadian ke pihak terkait seperti: Kepala Instalasi, Manajemen Keperawatan, Pencegahan dan Pengendalian Infeksi (PPI), dan Intalasi Pemeliharaan Saran Rumah Sakit (IPS-RS). Peran ini termasuk peran manajer sebagai juru bicara yaitu mewakili ruangannya untuk menghadapi pihak luar (Moorhead \& Griffin, 2012), serta peran manajer sebagai negosiator yaitu mencari dukungan ke pihak direksi untuk menciptakan tempat kerja yang lebih aman (Jones, Lankshear \& Kelly, 2016). Tujuan dari pelaporan ini menurut Hadipoetro (2014) adalah sebagai bahan pembelajaran terkait kondisi lingkungan kerja kita, bahkan kejadian yang hampir cederapun sebaiknya dilaporkan. Hasil akhir dari proses identifikasi ini diharapkan bisa menjadi bahan pertimbangan untuk merekomendasikan perbaikan fasilitas atau kebijakan ke direktur rumah sakit.

\section{KESIMPULAN}

Berdasarkan hasil penelitian ini dapat disimpulkan bahwa kepala ruangan menyadari pekerjaan sebagai perawat berisiko tinggi tertular penyakit, mengalami stres dan risiko cedera. Mengatasi hal tersebut, kepala ruangan berusaha mengidentikasi penyakit dan kecelakaan akibat kerja yang dialami perawat, menganalisis penyebab dan efek kecelakaan tersebut pada perawat, serta melaporkan kejadian tersebut ke bidang yang terkait sebagai bahan evaluasi agar hal tersebut tidak terjadi di waktu yang akan datang.

Penelitian ini merekomendasikan penelitian berkelanjutan melalui riset kualitatif pengalaman perawat yang mengalami penyakit atau kecelakaan akibat kerja, sedangkan untuk riset kuantitatif tentang persentase kejadian penyakit dan akibat kerja yang sering dialami perawat.

\section{DAFTAR} PUSTAKA
Achmadi, U.F. (2014). Kesehatan masyarakat: Teori dan aplikasi. Jakarta: Rajawali Pers. 
Afiyanti, Y. \& Rachmawati, I.N. (2014). Metodologi penelitian kualitatif dalam riset keperawatan. Jakarta: Rajawali Pers.

Al-Ali, N.M., Al Faouri, I., \& Al-Niarat, T.F. (2015). The impact of training program on nurses' attitudes toward workplace violence in Jordan. Applied Nursing Research, 30, 83-89. DOI:10.1016/i.apnr.2015.11.001

Chen-Yin, T., Chia-Chen, C., Jin-Lain, M., \& Keh-Ping, C. (2014). Occupational hazards education for nursing staff through web-based learning. International Journal of Environmental Research and Public Health, 11, 13035-13046. http://doi.org/10.3390/ijerph111213035

De Mendonca, A.E.O., De Oliveira, A.V.T., Neto, V.L.S., \& Da Silva, R.A.R. (2015). Profile accidents involving nurses in the intensive care environment/Perfil de acidentes de trabalho envolvendo profissionais de enfermagem no ambiente da terapia Intensiva/Perfil de accidentes de trabajo que involucran a profesionales de enfermería en el ámbito de cuidados intensivos. Enfermería Global, 14(3), 211-218. Retrieved from http://search.proquest.com/docview/1708167093?accountid=17242

Dharma, K.K. (2011). Metode penelitian keperawatan, panduan melaksanakan dan menerapkan hasil penelitian. Jakarta: Trans Info Media.

Efstathiou, G., Papastavrou, E., Raftopoulos, V., \& Merkouris, A. (2013). Prevalence of occupational exposure to pathogens and reporting behaviour among Cypriot Nurses. International Journal of Caring Sciences, 6(3), 420431. Retrieved from http://www.internationaljournalofcaringsciences.org/docs/15.\%20Efstathio $\underline{\text { u.pdf }}$

Fasanya, B.K. \& Dada, E.A. (2015). Workplace violence and safety issues in longterm medical care facilities: nurses' perspectives. Safety and Health at Work, 1-5.

Hadipoetro, S. (2014). Manajemen komprehensif keselamatan kerja. Jakarta: Yayasan Patra trbiyah Nusantara. 
Hu, S.X., Luk, A.L., \& Smith, G.D. (2015). The effects of hazardous working conditions on burnout in Macau nurses. International Journal of Nursing Sciences, 2(1), 86-92. doi:10.1016/j.ijnss.2015.01.006

International Labour Organization. (2016). Healthcare workers care for us, but who's caring forthem.. Retrieved from: https://iloblog.org/2016/04/07/healthcare-workers-care-for-us-but-whoscaring-for-them/.

Jones, A., Lankshear, A. \& Kelly, D. (2016). Giving voice to quality and safety matters at board level: a qualitative study of the experiences of executive nurses working in England and Wales. International Journal of Nursing Studies. http://dx.doi:10.1016/j.ijnurstu.2016.04.007.

Kondarus, D. (2012). Keselamatan kesehatan kerja: Membangun SDM pekerja yang sehat, produktif dan kompetitif. Jakarta: Bangka Adinatha Mulia.

Kozier, B., Erb, G., Berman, A. \& Synder, S. (2010). Buku ajar fundamental keperawatan: Konsep, proses \& praktik (edisi ke-7).(Pamilih Eko Karyuni \& Dwi

Lindsey, C., Hutchinson, M., \& Mellor, G. (2015). The nature and hazards of diathermy plumes: A Review. AORN Journal, 101(4), 428-442. http://doi.org/10.1016/i.aorn.2015.01.021

Marquis, B.L. \& Huston, C.J. (2010). Kepemimpinan dan manajemen keperawatan: Teori dan aplikasi (edisi ke-4). (Widyawati, Wilda Eka handayani \& Fruriolina Ariani, Penerjemah). Jakarta: EGC. (Karya asli diterbitkan 2003)

Mcintosh, B. \& Sheppy, B. (2013). Effect of stress on nursing integrity. Nursing Standard, 27(25), 35-40

Mitrousi, S., Travlos, A., Koukia, E., \& Zyga, S. (2014). The experience of anxiety in nursing staff in public hospitals of Peloponnese, Greece. International Journal of Caring Sciences, 7(1), 188-194. Retrived from http://search.ebscohost.com/login.aspx?direct=true \&db=rzh\&AN=20125142 $\underline{61 \& \text { site=ehost-live }}$ 
Moorhead, G. \& Griffin, R.W. (2012). Managing organizational behavior (10 ${ }^{\text {th }}$ Ed). Mason, $\mathrm{OH}$ : South-Western.

Polit, D.F., \& Beck, C.T. (2012). Nursing research, generating and assesing evidence for nursing practice $\left(9^{\text {th }} e d\right)$. China: Lippincot Williams \&Wilkins.

Ramacciati, N., Ceccagnoli, A., \& Addey, B. (2015). Violence against nurses in the triage area: An Italian qualitative study. International Emergency Nursing, 23(2015), 274-280. http://dx.doi.org/10.1016/j.ienj.2015.02.00

Rogers, B., Buckheit, K., \& Ostendorf, J. (2013). Ergonomics and nursing in hospital environments. Workplace Health \& Safety, 61(10), 429-439. http://doi.org/10.3928/21650799-20130916-09

Shimizu, H.E., Couto, D.T., Hamann,E.M., \& Branco, A.B. (2010). Occupational health hazards in ICU nursing staff. Nursing Research and Practice, 2010, 16. http://dx.doi.org/10.1155/2010/849169

Shu-Ti, C., Jen-Huai, C., Huang, N., Chih-Hsun, W., \& Li-Yin, C. (2013). Health issues among nurses in Taiwanese hospitals: National survey. International Journal of Nursing Studies, 50(10), 1377-1384. DOI:http://dx.doi.org/10.1016/j.ijnurstu.2013.01.012

Yeoh, H. T., Lockhart, T.E., \& Wu, X. (2013). Nonfatal occupational falls among U.S. health care workers, 2008-2010. Workplace Health Safety, 61(1), 3-8. http://doi.org/10.3928/21650799-20121221-52.Nonfatal

Zavala, Q.M.O., Suazo, V.S., \& Klijn P.T. (2014). Nursing from the perspective of decent work. Enremeria Global. 310-317. Retrieved from http://remotelib.ui.ac.id:2073/docview/1664837383/fulltextPDF/83F171B96E4A4311PQ/1 ?accountid=17242 